\title{
ОМЕЛА БЕЛАЯ VISCUM ALBUM L. (LORANTHACEAE) И «ВЕДЬМИНА МЕТЛА» (ПРОЛИФЕРАЦИЯ) В ВОРОНЕЖСКОЙ ОБЛАСТИ
}

\author{
О. В. Якименко, А. Я. Григорьевская, М. А. Терновец \\ Воронежский государственный университет, Россия \\ Поступила в редакцию 12 октября 2018 г.
}

\begin{abstract}
Аннотация: Приводятся сведения об ареале редкого кустарника полупаразита омелы белой Viscum album (Loranthaceae) на территории Воронежской области. Рассматриваются причины поражения древесных растений «ведьминой метлой», ее распространении и опасности для дендрофлоры.

Ключевые слова: соматическая мутация, ведьмина метла, полупаразит, омела, Воронежская область.
\end{abstract}

\section{Mistletoe Viscum album L. (Loranthaceae) and the witch's broom (proliferation) in the Voronezh Region}

\section{O. V. Yakimenko, A. Ya. Grigor'yevskaya, M. A. Ternovets}

\begin{abstract}
Information regarding the habitat of rare shrub-polyparasitic mistletoe Viscum album (Loranthaceae) on the area of the Voronezh region has been given. The causes of damage to woody plants «witch's broom», its spread and danger to dendroflora have been considered.
\end{abstract}

Key words: somatic mutation, witch's broom, semi-parasite, mistletoe, Voronezh region.

Viscum album L. имеет широкое распространение Кавказ - юг Скандинавии, средняя и атлантическая Европа, Средиземноморье, Малая Азия, Африка [12]. Ее ареал совпадает с распространением широколиственных лесов, равнин, предгорий и горных склонов. Она является полупаразитами способна синтезировать органические вещества благодаря наличию автономной хлорофиллоносной системы. Обитает чаще всего высоко в кронах деревьях. Влагу и минеральные вещества получает от хозяина, проникая своими корнями глубоко под кору. Образует вильчато-ветвящийся шаровидные и полушаровидные кусты на дереве [4].

Известно 32 вида древесно-кустарниковых пород, на которых встречается Viscum album. Омела предпочитает деревья мягких пород, со слабым пробковым слоем. В средней полосе России отмечена на Populus nigra на старовозрастных деревьях Pyrus communis, Malus domestica, реже на видах родов Salix, Tilia, Ulmus, деревьях Carpinus betulus, Quercus robur, Juglans regia, Robinia pseudoacacia. На хвойных породах, таких как 2019

() Якименко О.В., Григорьевская А.Я., Терновец М.А.,
Juniperus communis, Abies sibirica, Pinus sylvestris, Viscum album встречается крайне редко, так как на них отмечается $V$. austriacum Wiesb с определенными признаками отличия. Однако впоследствии эти признаки оказались не постоянными.

На одном дереве кусты омелы белой могут быть разных размеров и возраста. Чаще всего заражаются ослабленные старовозрастные породы деревьев с мягкой древесиной, приуроченные к долинам рек, увлажненным балкам, старинным усадебным паркам, реже городским насаждениям.

Распространение Viscum album происходит эндозоохорным путем, в основном птицами. Ягоды у омелы ядовиты для человека, но съедобны для птиц, а семена содержат клейковину - висцен, благодаря этому в народе ее называют птичья омела или птичий клей. Семя прилипает к клюву птиц, при перелете на другие деревья птица пытается очистить клюв о дерево, тем самым семя закрепляется на коре. Семя не теряет свою клейкость даже после прохождения через пищеварительный тракт птиц. С экскрементами переносится на деревья, проникает в микротрещины и прорастает весной, укрепляя свою корневую систему [2]. 
Viscum album указана для Воронежской (вблизи г. Бутурлиновка) $[1,8]$, Белгородской, Курской, Брянской областей. Занесена в Красные книги Смоленской [7], Курской [6] областей. В Курской области встречается на крайнем юге, однако имеет тенденцию к расширению ареала на север и восток [10].

Впервые на территории Воронежской области она указывалась Е. Г. Гнатенко на Липовской даче Бутурлиновского района [3]. Однако в сводке для Воронежской области Н. С. Камышевым не отмечена [5]. В настоящее время она массово паразитирует на Quercus robur L. в Бобровском районе юго-восточнее села Липовка в Боярском (Казенном) лесу по берегу реки Битюг на протяжении почти 4 км; в селе Шестаково, ул. Московская, на тополе пирамидальном. В селе Липовка в окрестности автозаправочной станции в 2013 году омела была обнаружена на тополе пирамидальном, в средней части кроны [9].

В 2018 году Viscum album отмечена нами в Каменском районе окрестности хутора Шапашниково в остатках насаждения старинного парка бывшей усадьбы Кулешовых-Безбородко-Волконских Она паразитирует в верхней части кроны старовозрастной Pyrus communis и имеет в окружности более $60 \mathrm{~cm}$.

«Ведьмина метла» (BM) - вихоревы гнезда или пролиферация. Вопрос о природе их возникновения до сих пор не решен. Наиболее распространены предположения об инфекционном заражении различными видами ржавчинных грибов рода Taphrina, вирусами чаще фитоплазма Potato witches broom и галловыми клещами, а также мутационной природой ведьменых метел.

Возбудители чаще попадают в трещины коры от мороза, ветровала, бурелома, снеголома. Преимущественно страдают старовзрастные деревья и кустарники. На них появляются утолщения и наросты, закладывается большое скопление спящих почек. В разгар вегетации вырастает шарообразный ком тонких прямых побегов с короткими междоузлиями и аномальными прилистниками. Древесина у них более плотная и прочная, чем у ветвей дерева той же породы и имеет свилеватую структуру. Кора на них - красно-оранжевого оттенка, листья мелкие, желтеют раньше других.

Грибы рода Taphrina поражают около 100 видов древесных лиственных пород. Так Taphrina acericola поражает виды из рода Acer, a Taphrina betulina виды рода Betulaceae. Вирусные ВМ (си- нонимы: «израстание», «кустистость») характеризуются разрастанием прикорневой густой поросли.

Болезни подвержены чаще всего Betula veru$\cos a$, а из хвойных - Pinus sylvestris. Среди культурных плодовых деревьев от вирусных поражений чаще страдают Pyrus communis и Malus domestica, а от грибной инфекции - Prunus cerasus. Способы распространения этих форм заболевания изучены недостаточно. Вирусное заражение вероятно происходит через крылатое поколение тли, а споры грибов распространяются эндозоохорным путем и ветром.

Мутационная природа заболевания сопровождается появлением мутаций в меристемах растения. Благодаря способности передавать свои признаки последующим поколениям многие виды используются для выведения новых форм растений $[15,16,17,18]$. На их основе получены сотни сортов плодово-ягодных и декоративных растений. Семенное и вегетативное потомство ВМ чаще хвойных растений обладает такими высокими декоративными свойствами как: густым и обильным ветвлением, ранней вегетацией, замедленным ростом, короткохвойностью [11].

Возрастающее загрязнение атмосферного воздуха, особенно в промышленных городах, способствует частой встречаемости ВМ у некоторых лиственных пород деревьев [14]. Исследование встречаемости ВМ у Pinus sylvestris в лесном массиве Московской области вблизи автодороги с интенсивным движением автотранспорта выявило, что на 900 деревьев встречается 1 ВМ, что в 8 раз выше фоновой встречаемости - 1 ВМ на 7200 деревьев. Распределение ВМ на пробных площадях было не равномерным. Так, 70 \% ВМ обнаружено в пределах 200 м зоны от автодороги. Восьмикратное увеличение встречаемости ВМ вблизи автодороги указывает на способность выхлопных газов вызывать мутации у Pinus sylvestris [14].

В Казахстане В. В. Шульга отмечает заболевание Pinus sylvestris до 5 \% деревьев в древостое [13].

В Тюменской области в пределах Ямало-Ненецкого автономного округа на горельниках находится большое число заболевших молодых и ослабленных деревьев Pinus sylvestris. Размер, возраст и расположение на дереве ВМ самое разное.

В Воронежской области ВМ встречаются редко. В 2013 году в лесном массиве на Pinus sylvestris L. Она обнаружена в окрестностях села Ширяево Калачеевского района. Расположена ВМ в нижней части кроны дерева около 2,5 метров от земли. Имеет среднюю плотность, шаровидную правиль- 
ную форму, диаметром более 80 см. В 2018 году нами при обследовании старинного усадебного парка в Каменском районе, в окрестности хутора Шапашниково, обнаружены ВМ на старовозрастных деревьях Pyrus communis и Malus domestica. Все плодовые деревья заражены от нижней части кроны и до вершины. Форма ВМ чаще шаровидная, немного растянута к низу, плотность разная. Наиболее плотные ветви находятся в нижней части кроны. Побеги их поражены листоверткой, грушевым галловым клещом и другими вредителями.

Итак, приведенные сведения констатируют расширения ареала Viscum album в северо-восточном и восточном направлениях. Интенсивное ее распространение за последние десятки лет вызывает опасения за старовозрастную дендрофлору Воронежской области. Прогнозируемое увеличение ареала, возможно связано с частыми лесными пожарами.

\section{СПИСОК ЛИТЕРАТУРЫ}

1. Бейлин И. Г. Омела (Viscum album L.) в Западной Европе и в СССР / И. Г. Бейлин // Труды Института леса AH CCCP. - 1950. - T. 3. - C. 328-350.

2. Бейлин И. Г. Цветковые полупаразиты и паразиты / И. Г. Бейлин. - Москва : Наука, 1968. - 119 с.

3. Гнатенко Е. Г. Коварная омела / Е. Г. Гнатенко // Воронежские просторы. - Воронеж : Центрально-Черноземное книжное издательство, 1972. - С. 19.

4. Добрыня Ю. М. Исследование географического распространения, анатомического строения и зольных элементов омелы белой (Viscum album L.) на территории города Ставрополя / Ю. М. Добрыня // Научно-методический электронный журнал «Концепт». - 2013. T. 3. - C. 1361-1365.

5. Камышев Н. С. Флора Центрального Черноземья и ее анализ / Н. С. Камышев. - Воронеж : Издательство Воронежского государственного университета, 1978. $116 \mathrm{c}$.

6. Красная книга Курской области. - Тула : Гриф и $K^{\circ}, 2001$. - Т. 2 : Редкие и исчезающие виды растений и грибов. -165 с.

7. Красная книга Смоленской области. - URL : http://www.redbook67.ru. (дата обращения 06.06.2019).

8. Маевский П. Ф. Флора средней полосы европейской части России / П. Ф. Маевский. - 10-е изд. - Москва : КМК, 2006. - 600 с.

9. Новые сведения о редких растениях Центрального Черноземья России / А. Я. Григорьевская [и др.] // Флора и растительность Центрального Черноземья 2014 : материалы межрегиональной научной конференции (г. Курск, 5 апреля 2014 г.). - Курск, 2014. - С. 10-15.

10. Полуянов А. В. Современное распространение Viscum album L. в Курской области / А. В. Полуянов, Н. И. Дегтярев, Е. А. Скляр // Флора и растительность
Центрального Черноземья - 2013 : материалы научной конференции (г. Курск, 6 апреля 2012 г.). - Курск : Курский государственный университет, 2012. - С. 72-74.

11. Торчик В. И. Перспективы использования спонтанных соматических мутаций в селекции декоративных форм сосны обыкновенной (Pinus sylvestris L.) / В. И. Торчик // Наука и инновации. - 2011. - № 8. C. 67-70.

12. Цвелев Н. Н. Род Омела Viscum L. / Н. Н. Цвелев // Флора Восточной Европы. - Санкт-Петербург : Мирисемья - 95, 1996. - Том IX. - С. 409.

13. Шульга В. В. О карликовой форме сосны и «ведьминой метле» / В. В. Шульга // Лесоведение. 1979. - № 3. - С. 82-86.

14. Щербинина А. А. Структурные аномалии крон древесных растений придорожной полосы МКАД / А. А. Щербинина // Вестник Московского государственного университета леса. Лесной вестник. - 2004. № 4(35). - C. 64-71.

15. Brown C. L. Morphological and histological differences in development of dwarf mutants of sexual and somatic origin in diverse woody taxa / C. L. Brown, H. E. Sommer, H. Wetzstein //Trees : structure and function. - 1994. - № 9(2). - P. 61-66.

16. Waxman S. Variability in rooting and survival of cuttings from white pine witches' broom seedlings / S. Waxman // Proc. Int. Plant Prop. Society. - 1969. Vol. 19. - P. 338-344.

17. Waxman S. Witches' brooms sources of new and dwarf forms of Picea, Pinus and Tsuga species / S. Waxman // Acta Hort. Symposium on propagation in Arboriculture. - 1975. - № 54. - P. 25-32.

18. Waxman S. Dwarf conifers from witches' brooms / S. Waxman // Comb. Proc. Intern. Plant Propagators Soc. 1987. - Vol. 36. - P. 131-136.

\section{REFERENCES}

1. Beylin I. G. Omela (Viscum album L.) v Zapadnoy Evrope i v SSSR / I. G. Beylin // Trudy Instituta lesa AN SSSR. - 1950. - T. 3. - S. 328-350.

2. Beylin I. G. Tsvetkovye poluparazity i parazity / I. G. Beylin. - Moskva : Nauka, 1968. - 119 s.

3. Gnatenko E. G. Kovarnaya omela / E. G. Gnatenko // Voronezhskie prostory. - Voronezh : Tsentral'no-Chernozemnoe knizhnoe izdatel'stvo, 1972. - S. 19.

4. Dobrynya Yu. M. Issledovanie geograficheskogo rasprostraneniya, anatomicheskogo stroeniya i zol'nykh elementov omely beloy (Viscum album L.) na territorii goroda Stavropolya / Yu. M. Dobrynya // Nauchno-metodicheskiy elektronnyy zhurnal «Kontsept». - 2013. - T. 3. S. 1361-1365.

5. Kamyshev N. S. Flora Tsentral'nogo Chernozem'ya i ee analiz / N. S. Kamyshev. - Voronezh : Izdatel'stvo Voronezhskogo gosudarstvennogo universiteta, 1978. - $116 \mathrm{~s}$.

6. Krasnaya kniga Kurskoy oblasti. - Tula : Grif i K ${ }^{\circ}$, 2001. - T. 2 : Redkie i ischezayushchie vidy rasteniy i gribov. $-165 \mathrm{~s}$. 
7. Krasnaya kniga Smolenskoy oblasti. - URL : http:// www.redbook67.ru. (data obrashcheniya 06.06.2019).

8. Maevskiy P. F. Flora sredney polosy evropeyskoy chasti Rossii / P. F. Maevskiy. - 10-e izd. - Moskva : KMK, 2006. $-600 \mathrm{~s}$.

9. Novye svedeniya o redkikh rasteniyakh Tsentral'nogo Chernozem'ya Rossii / A. Ya. Grigor'evskaya [i dr.] // Flora i rastitel'nost' Tsentral'nogo Chernozem'ya - 2014 : materialy mezhregional'noy nauchnoy konferentsii (g. Kursk, 5 aprelya 2014 g.). - Kursk, 2014. - S. 10-15.

10. Poluyanov A. V. Sovremennoe rasprostranenie Viscum album L. v Kurskoy oblasti / A. V. Poluyanov, N. I. Degtyarev, E. A. Sklyar // Flora i rastitel'nost' Tsentral'nogo Chernozem'ya - 2013 : materialy nauchnoy konferentsii (g. Kursk, 6 aprelya 2012 g.). - Kursk : Kurskiy gosudarstvennyy universitet, 2012. - S. 72-74.

11. Torchik V. I. Perspektivy ispol'zovaniya spontannykh somaticheskikh mutatsiy v selektsii dekorativnykh form sosny obyknovennoy (Pinus sylvestris L.) / V. I. Torchik // Nauka i innovatsii. - 2011. - № 8. - S. 67-70.

12. Tsvelev N. N. Rod Omela Viscum L. / N. N. Tsvelev // Flora Vostochnoy Evropy. - Sankt-Peterburg : Mirisem'ya - 95, 1996. - Tom IX. - S. 409.

\section{Якименко Ольга Владимировна}

аспирант кафедры геоэкологии и мониторинга окружающей среды факультета географии, геоэкологии и туризма Воронежского государственного университета, г. Воронеж, т. 8(473)266-56-54, E-mail: zemfirka@inbox.ru

Григорьевская Анна Яковлевна

доктор географических наук, профессор кафедры геоэкологии и мониторинга окружающей среды факультета географии, геоэкологии и туризма Воронежского государственного университета, г. Воронеж, т. 8(473)266-56-54, E-mail: grigaya@ mail.ru Терновец Маргарита Андреевна

бакалавр факультета географии, геоэкологии и туризма Воронежского государственного университета, г. Воронеж, т. 8(473)266-56-54, E-mail: rternovec@mail.ru
13. Shul'ga V. V. O karlikovoy forme sosny i «ved'minoy metle»/V. V. Shul'ga //Lesovedenie. -1979. -№ 3. -S. 82-86.

14. Shcherbinina A. A. Strukturnye anomalii kron drevesnykh rasteniy pridorozhnoy polosy MKAD / A. A. Shcherbinina // Vestnik Moskovskogo gosudarstvennogo universiteta lesa. Lesnoy vestnik. - 2004. - № 4(35). -S. 64-71.

15. Brown C. L. Morphological and histological differences in development of dwarf mutants of sexual and somatic origin in diverse woody taxa / C. L. Brown, H. E. Sommer, H. Wetzstein // Trees : structure and function. - 1994. - № 9(2). - P. 61-66.

16. Waxman S. Variability in rooting and survival of cuttings from white pine witches' broom seedlings / S. Waxman // Proc. Int. Plant Prop. Society. - 1969. - Vol. 19. P. 338-344.

17. Waxman S. Witches' brooms sources of new and dwarf forms of Picea, Pinus and Tsuga species / S. Waxman // Acta Hort. Symposium on propagation in Arboriculture. - 1975. - № 54. - P. 25-32.

18. Waxman S. Dwarf conifers from witches' brooms / S. Waxman // Comb. Proc. Intern. Plant Propagators Soc. 1987. - Vol. 36. - P. 131-136.

Yakimenko Olga Vladimirovna

Postgraduate student of the Department of Geoecology and Environmental Monitoring of the Faculty of Geography, Geoecology and Tourism, Voronezh State University, Voronezh, tel. 8(473)266-56-54, E-mail: zemfirka@inbox.ru

Grigor'yevskaya Anna Yakovlevna

Doctor of Geographical Sciences, Professor of the Department of Geoecology and Environmental Monitoring of the Faculty of Geography, Geoecology and Tourism, Voronezh State University, Voronezh, tel. 8(473)266-56-54, E-mail: grigaya@mail.ru

Ternovets Margarita Andreyevna

Student of the Faculty of Geography, Geoecology and Tourism, Voronezh State University, Voronezh, tel. 8(473)266-56-54, E-mail: rternovec@ mail.ru 